\title{
DVAITA VEDANTA DALAM TEKS LONTAR BHUWANA MAHBAH
}

Oleh:

Mery Ambarnuari, S.Ag., M.Ag

\begin{abstract}
Abstrak
Perkembangan dan penyebaran ajaran agama Hindu menjadikan pustaka suci Veda memiliki bagianbagian teks yang sangat banyak, salah satunya merupakan teks-teks yang bersifat kedaerahan yang ditulis dengan mengutip ajaran-ajaran dalam pustaka suci Veda. Teks lontar Bhwwana Mahbah merupakan salah satunya. Teks yang membahas tentang penciptaan dan pemeliharaan alam semesta ini mengandung ajaran yang bersesuaian dengan Dvaita Vedanta yang dualis, yang dimana antara Tuhan yang menciptakan alam semesta berbeda dengan ciptaanya namun ciptaannya masih dalam kendali Tuhan sebagai realitas tertinggi.
\end{abstract}

\section{Kata kunci: Dvaita, Bhuwana Mahbah}

\section{Abstract}

The development and dissemination of Hindu teachings makes the Vedas Holy Library A lot of text passages, one of which is the regional texts written by citing the teachings in the Vedic Sacred Library. The text of Bhuwana Mahbah Lontar is one of them. The text discussing the creation and preservation of the universe contains teachings that correspond to the dualist Dvaita Vedanta, which, among others, created the universe different from its creations but the creation is still in control God as the ultimate reality.

\section{Keywords: Dvaita, Bhuwana Mahbah}

\section{Pendahuluan}

Secara historis, semua ilmu pengetahuan yang dikenal dewasa ini pernah menjadi bagian dari filsafat sehingga filsafat dianggap sebagai induk dari segala ilmu pengetahuan atau the mother of science. Seiring dengan perkembangan zaman serta peradaban manusia, ilmu pengetahuan yang pada mulanya menjadi satu dengan filsafat mulai melebarkan sayapnya untuk mencari tujuan masing-masing.

Meskipun dalam perkembangannya setiap ilmu memisahkan diri dari filsafat, ini tidak berar- 
ti antara ilmu-ilmu khusus dan filsafat tidak ada hubungannya sama sekali. Tetap masih ada ciri khusus dan batasan-batasan yang tegas yang dimiliki oleh setiap ilmu (Maksum, 2014: 22). Sebagai induk dari ilmu pengetahuan, filsafat tentu saja mampu melingkupi segala ilmu pengetahuan yang ada termasuk kedalam agama. Agama menurut E.B Tylor merupakan kepercayaan kepada wujud yang spiritual (the believe in spiritual beings), selanjutnya Tylor membedakan antara yang suci dan yang agung (the sacred and the sublime) (Bakhtiar, 2007: 12). Agama sebagai ilmu pengetahuan tentu saja tak bisa terlepas dari filsafat karena hadirnya agama sebagai ilmu pasti didapatkan melalui pengetahuan, aktivitas dan melalui suatu metode tertentu.

Ada berbagai macam agama dan aliran kepercayaan di muka bumi ini, Hindu merupakan salah satunya. Agama Hindu merupakan agama yang lahir di lembah Sungai Sindhu di India, dalam masa perkembangannya, agama Hindu menyebar ke berbagai daerah hingga ke wilayah nusantara yang sekarang dikenal dengan Indonesia. Agama Hindu mempunyai Veda sebagai kitab sucinya yang dimana ajaran Veda ini bersifat universal dan fleksibel sehingga Agama Hindu meyakini ajarannya akan selalu ada sepanjang zaman.

Agama Hindu memiliki sistem filsafatnya tersendiri yang disebut dengan Nawa Darsana. Aliran-aliran filsafat nya sesuai dengan prinsip penggolongan tradisional dibagi menjadi dua kelompok besar yaitu: aliran filsafat ortodoks (astika) dan aliran filsafat heterodoks (nastika). Kelompok pertama terdiri atas enam sistem filosofis utama (yang secara popular dikenal sebagai sad darsana), yaitu: Mimamsa, Vedanta,
Sankhya, Yoga, Nyaya, dan Vaisesika. Semuanya ini dianggap sebagai aliran ortodoks (astika), karena mereka menerima otoritas dari kitab-kitab Veda. Sedangkan aliran filsafat heterodoks terdiri dari tiga yang utama yang merupakan aliran filsafat materialistis seperti Carvaka, Baudhha, dan Jaina. Mereka disebut heterodoks (nastika) karena mereka tidak mempercayai otoritas Veda. Veda merupakan rekaman tentang kepustakaan India paling awal yang masih tersedia, dan selanjutnya pemikiran india, khususnya pertimbangan filosofisnya, sangat dipengaruhi oleh kitab-kitab Veda ini baik secara positif maupun negative (Maswinara, 1999: 6).

Seiring dengan penyebaran agama Hindu keluar dari India yang merupakan tempat kelahirannya, budaya Veda ini juga turut serta menjadi pedoman bagi agama-agama Hindu di berbagai belahan dunia termasuk di Indonesia. Di Indonesia sendiri, ajaran-ajaran agama Hindu telah banyak disadur kedalam daun lontar maupun kulit binatang ketika zaman kerajan-kerajaan Hindu di nusantara, beberapa di antaranya masih tersimpan dan dilestarikan oleh umat Hindu khususnya di Pulau Bali.

Lontar Bhuwana mahbah yang akan dikaji dalam tulisan ini merupakan teks yang isinya menceritakan tentang proses penciptaan alam semesta. Gagasan yang terdapat dalam teks ini menceritakan tentang proses penciptaan dan pemeliharaan alam semesta, namun uniknya teks lontar Bhuwana Mahbah ini mengandung ajaran Dvaita Vedanta yang akan dijabarkan dalam pembahasan. Lontar Bhuwana Mahbah sendiri berasal dari Grya Kecicang, Bebandem, Karangasem dan telah dialih aksara dan dialih 
bahasakan oleh Tim Penerjemah Unit Pelaksana Teknis (UPT) Pusat Dokumentasi Budaya Dinas Kebudayaan Provinsi Bali.

\section{Ajaran Dvaita Vedanta dalam Teks Lontar Bhuwana Mahbah}

Sistem filsafat Dvaita dikembangkan oleh Sri Madhvacarya yang bersumber dari Prasthana Traya, yaitu Upanisad, Bhagavadgita dan Brahma Sutra, yang merupakan sistem filsafat Dvaita atau dualis tak terbatas dan Vaisnavisme Madhva disebut SadVaisnavisme untuk membedakannya dengan Sri Vaisnavisme dari Ramanujacarya (Maswinara, 1999: 191). Madhva membuat perbedaan mutlak antara Tuhan, obyek-obyek yang bergerak maupun yang tidak bergerak dan hanya Tuhan saja yang merupakan realitas tidak bebas. Vedantanya Madhva merupakan ajaran perbedaan mutlak, yaitu suatu Atyanta-bheda-darsana, yang menegaskan 5 perbedaan besar (panca bheda), yaitu (1) perbedaan antara Tuhan dan Roh Pribadi, (2) perbedaan antara Tuhan dan materi, (3) perbedaan antara roh pribadi dan materi, (4) perbedaan antara satu roh dengan roh lainnya dan (5) perbedaan antara materi yang satu dengan materi lainnya (Maswinara, 1999: 191-192).

Dvaita mengakui bahwa alam semesta ini nyata (ralistis), dan menerima adanya Tuhan yang berpribadi sebagai suatu kenyataan yang tertinggi. Segala sesuatu yang ada tergantung sepenuhnya kepada Tuhan. Tuhanlah yang menjadi sebab terjadinya alam semesta, Ia sebagai pencipta, pemelihara, dan pengendali semua yang ada.

Madhva menyebut ajaran Dvaita Vedanta (dualism) sebab pokok ajarannya adalah perbedaan (bheda). Disebut juga realistis karena mengakui bahwa alam semesta ini nyata, juga theistis karena menerima Tuhan yang berpribadi sebagai suatu kenyataan tertinggi. Semua bergantung kepada Tuhan sebagai sesuatu yang tertinggi. Dasar ajaran Madhva adalah mengakui adanya kenyataan yang beraneka ragam di dunia ini, semuanya mempunyai ciri dan sifat tersendiri, sehingga menimbulkan perbedaan-perbedaan. Padartha atau realitas objektif ada dua jenis, yaitu yang berdiri sendiri (svatantra) dan yang bergantung (paratantra). Tuhan sebagai keberadaan tertinggi sajalah yang merupakan realitas yang berdiri sendiri, sedangkan alam dan roh merupakan realitas yang bergantung pada Tuhan.

Ajaran Dvaita dalam Bhuwana Mahbah terlihat dari adanya proses penciptaan dan pemeliharaan alam semesta didalam Teks Bhuwana Mahbah.

Mangke mayoga Ida Hyang Śūnya, angrĕgĕp mantra aji utama wĕnang saking adnyana nirmala. Yeki suaranya, $\bar{A}$. Sandhi yoganira, wenang sakama-kama. Mangke mijil Sanghyang Mareka jati, Guru Tunggal,nga. Sanghyang Guru Reka (mayoga), mijil Sanghyang Tunggal, nga, Sanghyang Siwa Reka Mayoga Sanghyang Siwa Reka, mijil Sanghyang Parama Wiśesa. Mayoga Sanghyang Parama Wiśesa, mijil Sanghyang Taya, Mayoga Sanghyang Taya

(Bhuwana Mahbah 2b)

Terjemahan:

Maka Beliau Hyang Śunya beryoga, mengucapkan mantra ajaran utama (weda). 
Tercipta dari batin yang suci. Demikian nadaNya : A. pertemuan yoga-Nya. Dapat dipergunakan sekehendak-Nya. Maka lahirlah Sanghyang Mareka Jati. Disebut juga Guru Tunggal.

- Sanghyang Guru Reka beryoga, lahirlah Sanghyang Tunggal atau disebut Sanghyang Siwa Reka.

- Sanghyang Śiwa Reka beryoga, lahirlah Sanghyang Prama Wiśeșa.

- Sanghyang Prama Wiśeșa beryoga, lahirlah Sanghyang Taya.

Teks $2 \mathrm{~b}$ di atas menunjukkan bahwa Sanghyang Śunya sebagai causa prima dari keberadaan alam semesta. Beliau menciptakan ciptannya namun beliau tidak menjelma menjadi ciptaannya, karena penciptaan terjadi dari yoga Sanghyang Śunya sehingga Sanghyang Śunya berada di luar ciptaannya. Hal inilah yang menunjukkan bahwa konsepsi Ketuhanan dalam teks Bhuwana Mahbah adalah Monotheisme Transenden. Sanghyang Śunya sebagai causa prima telah mengadakan dirinya sendiri. Monotheisme transenden merupakan keyakinan yang memandang Tuhan Yang Maha Esa berada jauh diluar ciptaa-Nya. Tuhan Yang Maha Esa maha luhur, tidak terjangkau oleh akal pikiran manusia. Hal ini juga sejalan dengan Dvaita Vedanta. Dvaita menyatakan bahwa ada dua kategori dari kenyataan mutlak, yakni Brahman sebagai Tuhan personal yang merupakan kenyataan mutlak, dan jiwa serta individu dan obyek materi merupakan kenyataan yang relative yang berbeda satu dengan yang lainnya namun tetap bergantung pada Tuhan. Selanjutnya proses penciptaan dan pemeliharaan alam semesta dalam teks Bhuwana Mahbah semakin mengutkan adanya dualitas yang membedakan Tuhan dengan ciptaanya.

\section{a. Proses Penciptaan}

Donder (2007:4) menyatakan terdapat perbedaan antara Kosmologi Hindu dengan kosmologi yang umum dipelajari oleh ilmuwan Barat, kosmologi Hindu menempatkan Tuhan pada posisi pertama dan utama sebagai causa prima, "cikal bakal" (sangkan paraning dumadi) dari alam semesta ini. Kosmologi Hindu melihat penciptaan alam semesta atau jagat raya ini bermula dari Tuhan. Dari dalam badan atau kandungan Tuhan (hiranya garbha) alam semesta ini dilahirkan, dan kemudian kedalam kandungan Tuhan (hiranya garbha) pula alam semesta ini akan dikembalikan. Pendapat ini senada dengan apa yang termuat didalam Teks Bhuwana Mahbah yang menunjukkan bahwa Tuhan merupakan asal mula dan sumber dari segala yang ada di dunia ini.

Sloka 2a dan 2b dalam Teks Bhuwana Mahbah menunjukkan bahwa pada mulanya tidak ada apa-apa, kemudian dari ketidakadaan tersebut Tuhan mengadakan diri-Nya yang menjadi awal dan cikal bakal segala yang akan ada yang dalam teks ini disebut sebagai Sanghyang Śunya. Pada proses selanjutnya, Beliau melakukan Yoga. Hasil dari Yoga Beliau yang tak berwujud (Sunya) Nirguna) menciptakan manifestasi-Nya (Saguna) yang memiliki tugas dan fungsi untuk melanjutkan proses penciptaan alam semesta beserta isinya. Penjabaran dari proses penciptaan dalam Teks Bhuwana Mahbah dapat diklasifikasikan secara sederhana yang dimulai dengan 1). penciptaan 
para Dewa, 2). penciptaan unsur Panca Maha Bhuta, 3) Penciptaan isi alam semesta, penciptaan ajaran agama, dan 4). penciptaan profesi. Proses tersebut termuat dalam sloka nomor $2 \mathrm{~b}$ sampai dengan $4 \mathrm{a}$.

Penciptaan dalam teks Bhuwana Mahbah menunjukkan suatu proses yang vertikal. Dari Tuhan yang mengadakan dirinya sendiri (Sang Hyang Sunya) beliau beryoga maka pertamatama diciptakanlah para dewa, para dewa ini nantinya akan melanjutkan proses penciptaan dan pemeliharaan. Setiap yoga dari Sanghyang Śunya selalu menciptakan wujud manifestasi Tuhan (Saguna Brahman), yang memiliki wujud, tugas, fungsi, dan kekuatan yang tergambar dari gelar atau nama yang disandangnya. Proses selajutnya adalah wujud manifestasi Tuhan Yang Maha Esa tersebut melanjutkan proses penciptaan hingga akhirnya diciptakanlah Panca Maha Bhuta yakni pertiwi, akasa, apah, teja, bayu, langit, matahari, bulan, bintang, api, air , laut, dan bumi yang terjadi secara vertikal. Hal ini ditunjukkan oleh sloka 3a sampai 4a dalam teks Bhuwana Mahbah. Sanghyang Śunya beryoga melahirkan Sanghyang Mareka Jati/Guru Tunggal/Guru Reka. Sanghyang Guru Reka beryoga, lahirlah Sanghyang Tunggal atau disebut Sanghyang Siwa Reka. Sanghyang Śiwa Reka beryoga, lahirlah Sanghyang Prama Wiśeșa. Sanghyang Prama Wiśeșa beryoga, lahirlah Sanghyang Taya, demikian seterusnya sampai pada penciptaan unsur Panca Maha Bhuta yang didalam teks ini unsur Panca Maha Bhuta tersebut juga diklasifikasikan sebagai dewa. Hal ini dibuktikan dengan adanya kata "Sanghyang" yang mengawali penyebutan dari unsur Panca Maha Bhuta tersebut.
Penciptaan selanjutnya melahirkan langit, matahari, bulan, dan bintang yang merupakan benda-benda angkasa. Kelanjutan dari penciptaan unsur Panca Maha Bhuta adalah Penciptaan Isi Alam Semesta. Hal ini ditunjukkan oleh kalimat akhir pada teks 3b sampai pada teks 6b: penciptaan sagara atau lautan berasal dari yoga-Nya Sanghyang Śunya yang melahirkan Bhagawan Siwa Kresna dan lahir pula Sanghyang Sagara. Proses selanjutnya adalah bertujuan untuk menjaga apa yang telah diciptakan sebelumnya, oleh karena itu Sanghyang Śiwa Reka beryoga, lahirlah tanah (bumi) sebagai dasar ruang. Yoga dari Sanghyang Śūnya selanjutnya melahirkan Bhagawan Bhadawang Nala dan Sang Hyang Ananta boga sebagai dasar bumi. Kemudian Sanghyang Śūnya beryoga melahirkan penjaga langit, penjaga matahari, dan penjaga bulan. Penjaga langit ialah Sang Hyang Bapa Babu. Babu bernama I Srah, berdiam di samping lubang langit bagian tengah dan Babu bernama I Tanjek berdiam disamping lubang langit bagian kiri. $I$ Kirih Pugeh menjaga matahari, dan I Pita Tukup Jiwa menjaga Bulan. Sehingga benda-benda angkasa yang diciptakan sebelumnya dilengkapi dengan penjaganya masing-masing untuk lebih memaksimalkan tugas dan fungsinya. Asumsi terhadap adanya dewa penjaga untuk menjaga ciptaan yang telah tercipta ini menunjukkan bahwa Tuhan menciptakan wujud keilahian diriNya untuk menjaga keberlanjutan ciptaan-Nya.

Tahapan berikutnya adalah menciptaan isi dunia, yang bersumber dari yoga-Nya Sanghyang Guru Reka yang melahirkan semua ini, diantaranya ; para bidadara dan bidadari; para komara-komari, 
para deta-deti, dan Panca Rsi ; Rsi Korsika, Rsi Garga, Rsi Metri, Rsi Kurusya dan Rsi Prětanjala. Sanghyang Śunya kembali beryoga, maka lahirlah laki, perempuan dan banci. Ialah yang menjadi Guru dari Mantaya, mantiga dan maharya.

Dijabarkan pula kedudukan aksara dalam proses penciptaan, sebagai kelanjutan proses penciptaan sebelumnya. Aksara juga memiliki peranan penting dalam proses penciptaan isi dunia terutama terkait dengan penciptaan ajaran-ajaran yang akan dianugerahkan kepada manusia karena aksara-aksara ini merupakan wahyu suci dari Tuhan yang sangat berperan dalam membantu kehidupan manusia di bumi. Sanghyang Saraswati, Sanghyang Kawiswara dan Sanghyang Guru Reka bertahta dalam aksara, hal ini mempertegas bahwa aksara-aksara tersebut merupakan aksara suci karena terdapat Tuhan yang berstana di dalamnya. Beliau menganugerahkan manfaat dari ajaran tersebut yang diturunkan melalui para bhatara dan Bhagawan. Ajaran yang diciptakan meliputi ajaran yang digunakan untuk mendekatkan diri kepada Tuhan sebagai rasa syukur manusia seperti ajaran agama, adigama dan dewagama; Ajaran tentang sesuatu yang bersifat gaib mulai dari ilmunya hingga segala penyakit yang disebabkan oleh ilmu hitam; Ilmu astronomi yang digunakan untuk menentukan baik buruknya hari dalam melakukan suatu kegiatan, yang meliputi: Sundari Bungkah, Sundari Terus dan Janantaka; Ilmu pengobatan yang bertujuan untuk menangani berbagai penyakit yang dialami oleh manusia, ajarannya meliputi Usadha, Dharma Usada dan Kalimosadha; Diciptakan pula ilmu Nujum, ajaran Tapa Brata dan ajaran Kamoksan, segala ajaran yang mengajarkan kebajikan dan dharma antara lain: kitab Kurante Bolong, Batur Kaliwasan petak, Panca Brahma, Patining Sad Rasa, Sara Śāstra Śamuscaya, Raja Peni, Kreta Kundalini, Jong Biru dan Dharma nglaras.

Penciptaan selanjutnya setelah penciptaan aksara ditunjukkan oleh teks $7 \mathrm{~b}$ yakni penciptaan profesi atau golongan pekerjaan yang dilakukan oleh manusia berdasarkan pengetahuan dan ajaran-ajaran yang sudah mereka dapatkan sebelumnya. Sanghyang Iśwara menciptakan para dalang, Sanghyang Indra menciptakan para seminan ukir, Sanghyang Brahma menciptakan pande besi, Sanghyang Mahadewa menciptakan pande Mas, Sanghyang Wisnu menciptakan pande Batu, Bhagawan Siwa Karma menciptakan tukang bangunan dan ilmu bangunan (Asta Kosala). Profesi-profesi ini merupakan pengaplikasian dari ajaran dalam kitab-kitab yang telah diciptakan sebelumnya dengan tujuan untuk mempermudah kehidupan manusia di bumi.

Diciptakan pula segala yang berkaitan dengan kehidupan manusia di bumi beserta golongan manusia dan asal dari manusia tersebut yang ditunjukkan oleh teks 8a Bhuwana Mahbah berikut: Sanghyang Bapa Babu menciptakan siang dan malam untuk mengatur waktu manusia dalam melaksanakan aktivitas. Para bidadara dan bidadari mengajarkan berbagai keahlian kepada para wanita dan mengajarkan tiga penyebab kebahagiaan bathin. Diciptakanlah manusia pertama di bumi oleh Sanghyang Wisnu dan Sanghyang Brahma. Sanghyang Brahma menciptakan orang laki-laki yang diberi nama Manu dan Sanghyang Wisnu menciptakan seorang wanita yang diberi 
nama Nini Manuh. Kemudian diciptakan empat golongan manusia oleh Sanghyang Kasuhunan kidul, empat golongan manusia tersebut adalah Brahmana, Ksatria, Wesya dan Sudra. Kemudian Sanghyang Giri Putri menciptakan tiga kelompok manusia yang dapat menguasai tiga keahlian utama yang menghantarkan manusia kepada Sanghyang Siwa Tiga (Siwa, Sada Siwa, Parama Siwa), untuk menghormati kemuliaan beliau Sanghyang Siwa Tiga maka manusia membuat sanggar rong tiga atau sanggar yang memiliki tiga ruangan untuk mengingat dan menghormati beliau yang telah menciptakan dan mengajarkan manusia dalam memusatkan pikiran menuju beliau.

Teks 8b Bhuwana Mahbah menjelaskan unsur yang membentuk manusia, saripati Akasa menjadi manusia laki-laki yang berasal dari sperma (kama putih/petak), dewanya Sanghyang Semara; Saripati Pretiwi menjadi manusia perempuan yang berasal dari sel telur (kama bang) dewanya Sanghyang Nareśwari; Saripati ruang/embang menjadi manusia banci berasal dari sperma biru (kama dadu) dewanya Nadhi Maya. Diatas ketiga dewa tersebut adalah: Sang Hyang Ongkara, Sanghyang Iswara, Sanghyang Isora, Sanghyang Rudra, Sanghyang Mahadewa Sanghyang Sangkara, Sanghyang Wisnu, Sanghyang Sambhu yang semuanya mengelilingi makrokosmos, menjaga perbuatan, perkataan dan pikiran.

Sanghyang Suryakanta membuat sesuatu yang kental. Sanghyang Kama, Sanghyang Siwa Reka, dan Sanghyang Guru Reka bersatu membentuk Sanghyang Kama. Sanghyang Kama kemudian mencari wujud pada isi alam untuk dijadikan sumber kehidupan, hal ini menunjukkan bahwa alam semesta dianggap sebagai mahluk kosmis atau manusia kosmis. Bṛhad'āranyaka Upanișad juga menyatakan bahwa penciptaan adalah jalan dari yadnya yang dimana seluruh alam semesta menjadi komponen didalamnya, mantramnya:

Aum. uṣa vā aśvasya medhyasya śirah, sūryas cakṣuḥ vātaḥ prānah, vyāttam agnir vaiśvānaraḥ; sam̃vatsara ātmāśvasya medhyasya, dyauh prștham, antarikșam udaram, prthivī pājasyam, diśah pārśve, avāntaradiśạ pārśavah ṛtavoñgāni, māsās cārdhamāsāś ca parvāṇi ahorātrāṇi pratișthāh, nakṣa-trāny asthīni, nabho māmsāni; ūvadhyaì sikatāh, sindhavo gudāh, yakṛc ca klomānaś ca parvatāh, oṣadhyayaś ca vanaspatayaś ca lomāni. Udyan pūrvārdhah, nimlocañ jaghanārdhah, yad vijgrmbhate tad vidyotate, yad vidhūnute tat stanayati, yan mehati tad varșati; vāg evāsya vāk.

(Bṛhad'āraṇyaka Upaniṣad I.1.1)

Terjemahan:

Aum, sesungguhnya, fajar adalah kepala dari kuda yajña, matahari adalah matanya, angin adalah nafasnya, mulut yang terbuka adalah api vaiśvānara; tahun adalah tubuh dari kuda yajña, langit adalah punggungnya, antariksa adalah perutnya, bumi sebagai telapak kakinya, mata angin sebagai sisi-sisinya, mata angin-antara adalah rusuk-rusuknya, musim adalah anggota-anggota tubuhnya, bulan dan tengah bulanan sebagai persendiannya, siang dan malam adalah kakinya, bintang-bintang adalah se- 
bagai tulangnya, mendung sebagai dagingnya, makanan dalam perut adalah sebagai pasirnya, sungai adalah urat darahnya, hati dan paru-paru adalah gunung-gunungnya, pohon-pohon obat dan pepohonan adalah rambutnya, matahari terbit adalah bagian depannya dan matahari terbenam bagian belakangnya, ketika ia menguap maka terjadilah petir dan ketika dia menggoyangkan tubuhnya maka terjadilah Guntur, ketika dia membuang air kecil terjadilah hujan; suara sesungguhnya adalah suaranya.

(Radhakrisna, 2008: 107)

Gambaran atau perumpamaan tentang Tuhan sebagai alam semesta sebagaimana uraian dalam teks Bhuwana Mahbah dan terdapat pula dalam mantram Bṛhad'āranyaka Upaniṣad di atas biasa disebut sebagai manusia kosmis atau manusia jagat raya (Donder, 2007:80). Hal ini menunjukkan bahwa untuk menggambarkan kesempurnaan Tuhan, segala partikel atau unsur terkecil dari zat (atom) yang ada-pun tak cukup digunakan. Segala tempat dijagat raya ini dipenuhi oleh Tuhan dan tidah ada suatu ruang, benda atau apapun yang tanpa kehadiran Tuhan didalamnya. Ini juga menunjukkan bahwa Tuhan meliputi semuanya dan tidak ada suatu apapun tanpa kehadiran Tuhan.

\section{b. Konsep pemeliharaan}

Penciptaan alam semesta oleh Tuhan tentunya memiliki suatu tujuan dan fungsi tertentu yang menyebabkan segala sesuatunya diciptakan, oleh karena itu setelah proses penciptaan tentu akan ada proses pemeliharaan sebagai tindak lan- jut dan sekaligus penjagaan terhadap semua yang telah diciptakan. Dalam teks Bhuwana Mahbah proses pemeliharaan tersebut ditunjukkan oleh teks 10b-11a berikut ini, dianugerahkannya biji kehidupan oleh Sanghyang Kasuhunan Kidul kepada manusia. Biji kehidupan ini yang kemudian tumbuh menjadi kunir dan tumbuh-tumbuhan lainnya yang dapat dimanfaatkan oleh manusia. Kemudian diciptakan catur jadma atau empat golongan manusia yaitu Brahmana, Ksatria, Wesya, dan Sudra yang selanjutnya masing-masing dari catur jadma ini diajarkan keterampilan yang nantinya diwariskan secara turun temurun sehingga sampai sekarang ada banyak keterampilan yang bisa dilakukan oleh manusia. Keterampilan tersebut diajarkan kepada catur jadma agar mempermudah kehidupan manusia didunia ini serta manusia dapat memberdayakan kemampuan diri sendiri ditambah dengan mengolah sumber daya yang disediakan dialam sehingga kehidupan didunia dapat terpelihari dengan baik.

Sanghyang Kasuhunan Kidul juga menciptakan berbagai hal sebagai anugerah kepada manusia, diantaranya: padi, ketan, injin, emas, perak, ruby, mutiara, intan, biduri, kuningan, lancing?, besi, tembaga, perunggu dan segala jenis permata. Padi, ketan, injin merupakan sumber makanan pokok yang dapat dikonsumsi sehari-hari oleh manusia, sedangkan berbagai jenis batu dan hasil tambang lainnya dapat digunakan sebagai perhiasan dan pakaian untuk membahagiakan kehidupan manusia. Oleh karena itu, kehidupan manusia di dunia dapat terpelihara dengan baik karena kebutuhan utama yaitu sandang, pangan, dan papan, bahan-bahannya telah tersedia dialam yang merupakan anugerah dari Tuhan melalui Sanghyang Kasuhunan Kidul. 
Terpelihara dan terjaganya kehidupan manusia didunia juga dapat membantu terpelihara dan terjaganya alam semesta sebab manusia merupakan mahluk ciptaan Tuhan yang memiliki derajat paling tinggi dibandingkan mahluk hidup lainnya. Maka dari itu manusia merupakan mahluk ciptaan Tuhan yang paling mulia sehingga dapat turut serta menjaga dan memelihara keberadaan tumbuhan, hewan, serta mahluk dan benda lainnya baik yang hidup maupun mati sebagai bentuk dari perpanjangan tangan Tuhan dalam menjaga dan memelihara alam semesta yang telah diciptakan tersebut.

Pemeliharaan tahap selanjutnya dilakukan untuk memperkokoh keagamaan manusia dalam menjalankan ajaran-ajaran yang diciptakan sebelumnya, maka dibuatlah sistem ritual yang terkait dengan tempat suci, hari suci, dan upacara yang lengkap dengan sesajan apa yang harus dihaturkan. Selain itu juga ditekankan pula ajaran Pitra Puja, yaitu dengan tidak melupakan pemujaan terhadap leluhur juga termuat dalam Kekawin Rāmāyana I:

\section{Gunamānta Sang Daśaratha,}

Wruh sira ring wéda bhakti ring déwa, tar malupéng pitrěpūja, māsih ta siréng swagotra kabéh. (prathamas sarggah. 3)

Terjemahan:

Gunawanlah Sang Dasarata. Pandai baginda dalam Weda, bakti kepada para dewa. Tidak lupa akan pemujaan leluhur. Bagindapun mengasihi dan menyayangi keluarganya semua.

(Sargah I.3)
Apa yang harus dilakukan, sarana dan upakara apa yang harus dihaturkan termasuk mantram yang digunakan juga telah termuat dalam teks Bhuwana Mahbah. Sehingga pada bagian akhir dari teks Bhuwana Mahbah mengajarkan bagaimana manusia menjalankan aktivitas keagamaan. Ajaran yang diciptakan sebelumnya dalam teks ini sudah dibentuk menjadi sesuatu yang lebih sistematis berupa suatu sistem agama yang meliputi tempat suci, hari suci, ritual-ritual, sarana ritual serta doa-doa pujian atau mantram yang digunakan dalam melakukan pemujaan atau persembahyangan.

Proses penciptaan dan pemeliharaan dalam teks Bhuwana Mahbah menunjukkan adanya perbedaan antara Tuhan sebagai Realitas tertinggi dengan mahluk-mahluk ciptaanya. Ini menandakan bahwa penekanan ajaran lima perbedaan dari Dvaita Vedanta sesuai dengan konsep Kosmologi maupun teisme dalam teks lontar Bhuwana Mahbah yakni antara Tuhan, Roh Pribadi, materi, antara roh pribadi dan materi, antara satu roh dengan roh lainnya dan antara materi yang satu dengan materi lainnya itu berbeda.

\section{Simpulan}

Ajaran Dvaita Vedanta dalam teks Bhuwana Mahbah ditunjukkan dalam proses penciptaan dan pemeliharaan alam semesta, yang dimana proses penciptaan dan pemeliharaan tersebut memposisikan Tuhan berbeda dengan segala sesuatu yang beliau ciptakan. Tuhan berdiri sendiri, sedangkan yang lainnya bergantung kepada Tuhan sebagai pencipta dan pengaturnya. 


\section{Daftar Pustaka}

Bakhtiar, Amsal. Filsafat Agama (Wisata Pemikiran dan Kepercayaan Manusia). Jakarta: Raja Grafindo Persada

Donder, I Ketut.2007. Kosmologi Hindu Penciptaan, Pemeliharaan, Peleburan dan Penciptaan Kembali Alam Semesta. Surabaya: Paramita.

Gunawan, I Ketut Pasek. 2012. Filsafat Hindu Nawa Darsana. Surabaya: Paramita

Maksum, Ali. 2014. Pengantar Filsafat. Yogyakarta: Ar-ruzz Media

Maswinara, I Wayan. 1999. Sistem Filsafat Hindu (Sarva Darsana Samgraha). Surabaya: Paramita

Radhakrishnan, S. 2008. Upaniṣad- Upanișad Utama. Surabaya: Paramita

Tim Penterjemah. 1987. Kekawin Rāmāyana I. Denpasar: Dinas Pendidikan Dasar Propinsi DATI I Bali 